\title{
SLUG FLOW VELOCITY ESTIMATION DURING PNEUMATIC CONVEYING OF BULK SOLID MATERIALS BASED ON IMAGE PROCESSING TECHNIQUES
}

\author{
Mateusz Miłak, Agnieszka Leszczyńska, Krzysztof Grudzień, Andrzej Romanowski, Dominik Sankowski \\ Lodz University of Technology, Institute of Applied Computer Science
}

Abstract. The article presents the use of fast cameras and image processing and analysis methods to determine the velocity of pneumatic transport of bulk material. The presented solution is dedicated to the analysis of dense flow in the form of slugs moving in a horizontal section of the pipeline. The developed image-processing algorithm is based on the estimation of the bulk solid material level in the pipeline in particular moments of the process. The acquisition of an image containing the area of two separate sections of the pipeline allows to determine the shift-time of material between two pre-defined pipeline regions. The obtained results indicate the proper action of the developed system.

Keywords: CCD camera, image processing, pneumatic conveying, flow velocity

\section{WYZNACZANIE PRĘDKOŚCI PRZEPLYWY KORKOWEGO W TRANSPORCIE PNEUMATYCZNYM MATERIALU SYPKIEGO W OPARCIU O TECHNIKI PRZETWARZANIA OBRAZÓW}

\begin{abstract}
Streszczenie. W artykule przedstawiono zastosowanie szybkich kamer oraz metod przetwarzania i analizy obrazów do wyznaczenia prędkości transportu pneumatycznego materiatu sypkiego. Przedstawione rozwiązanie dedykowane jest analizie zmian prędkości przeptywu gęstego w formie korków przemieszczajacych się $w$ poziomym odcinku rurociagu. Opracowany algorytmy przetwarzania obrazów opiera się na wyznaczeniu poziomu wypetnienia rurociagu materiatem sypkim w poszczególnych chwilach trwania procesu. Akwizycja obrazu zawierajacego obszar dwóch oddzielnych sekcji rurociagu pozwoliła na określenie czasu przejścia materiału między oboma, pre-definiowanymi, obszarami rurociagu. Uzyskane wyniki wskazuja na poprawne działanie opracowanego systemu.
\end{abstract}

Słowa kluczowe: kamera CCD, przetwarzanie obrazu, transport pneumatyczny, prędkość przepływu

\section{Introduction}

The dynamic development of many industries branches, like chemical, food, construction, mining, plastics, directly connected with new measurements techniques as answer to the need to monitor and control multiphase flows in technological processes [11]. For chemical process engineering a pneumatic transport, with particular emphasis on the transport of bulk solid materials over long distances, is very useful and safety type of gas-solid flow $[19,13]$. Pneumatic conveying, process of transporting bulk materials in a gas stream through a pipeline, is applied in industry, where granular material is main component of final product or occurs in intermediate stage of technological process The biggest advantage of used of this type of flow is its efficiency and robustness in transfer of granular materials over considerable distances. Additionally, proper designed pneumatic conveying system allows to achieve very low energy consumption. In order to achieve optimal flow control necessary is to determine the conveying characteristics of the bulk solid material. Results of better understanding of flow behavior are directly visible in better flow control system, providing new knowledge about process. The proper design of conveying system, in based on knowledge about process, causes increasing of flow efficiency. However, even correct designed conveying system needs flow control unit. The possibility of directly application of new measurements techniques, which are capable to enrich data in control unit, are very useful to prevent unwanted situation This is extremely important due to the possibility e.g. of reduced throughput of conveying system, or even blockage of installation. Such situations can causes stopping production process. Other troubleshooting problems are abrasive wear of pipeline, granular particle attrition, which can lead to low quality of product. The occurrence of such a situations may mean a halt in the production process and, in the worst case, damage to the installation. That is why it is so important to constantly monitor the entire process so that situations can be eliminated or properly controlled so that the whole process of flow to react to such phenomena [1]. The control unit in pneumatic conveying system mainly based on analysis of relation between the volume of air in the transport system and amount of bulk solid material flowing through the installation.
In order to better understand process necessary is to have full information about spatial-temporal changes of transported bulk solid material during changes of process conditions. Such information can be provide by apply industrial imaging techniques like process tomography or vision systems $[4,3,8,9,20]$.

\section{Industrial flow process visualization}

The flow imaging technologies include two main development paths, based on camera vision and process tomography systems. Both solutions provide information about process in case of images, which can be processed and analyzed to determined flow parameters [5, 23, 2, 7]. The obtained image of process is formed in different way. The camera visions system needs transparent installation; process tomography system can be applied for opaque installation. Depend on type of installation and aim of flow imaging, process investigation or control, choice of proper imaging technologies can be crucial for achieving the assumed objectives.

Often, techniques using capacitance of electrical tomography systems (ECT) are used to analyze such processes, [21, 10, 22, 12, $14,18]$. It is a helpful to visualize the distribution of transported material. In this way, you can study many different parameters, such as the level of occupancy the pipeline or calculate the speed of moving slugs. However, this is not the only method used to analyze flow parameters. Another equally interesting method is the acquisition of flow using CCD cameras. These are cameras that can record at $100 \mathrm{fps}$. The camera records the entire flow in the form of a film. Then, the recorded data is processed further using image processing algorithms. It is with their help that we are able to extract from the picture relevant information about the course. A more detailed description of the processing is in [6]. New image processing methods are still being developed to solve various problems. One example is the use of image processing to calculate the translational speed of the screw and the length of the liquid screw in the horizontal flow of the air water pipe (developed to quantitatively compute the translational velocity and slug liquid length in horizontal air-water pipe flow) [24].

Another example of the use of fast cameras is their use in flows where the granularity of loose materials is not of a regular shape [14]. The high-speed camera also works well in solids deposition in low-velocity slug flow pneumatic conveying [16]. 
They are also used to study Low-velocity pneumatic transport of bulk solids [15]. As present, there is a wide range of CCD cameras in analyzing multi-phase flows, both air-solid and air-water.

The present article describes the use of CCD camera and image processing for determine slug velocity during pneumatic conveying of bulk solid materials. The measurement section contains transparent sections of the horizontal pipeline. There is visible Electrical Capacitance Tomography sensor (ECT sensor), in the middle of the section, which divide image into two areas, A- in front of sensor, B - in behind of sensor.

a)

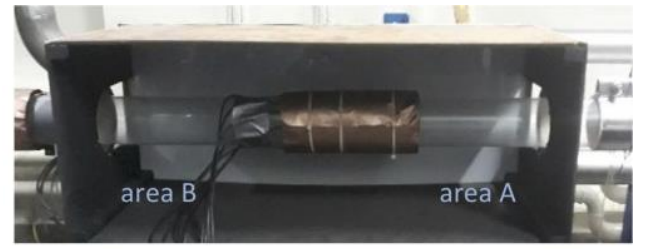

b)

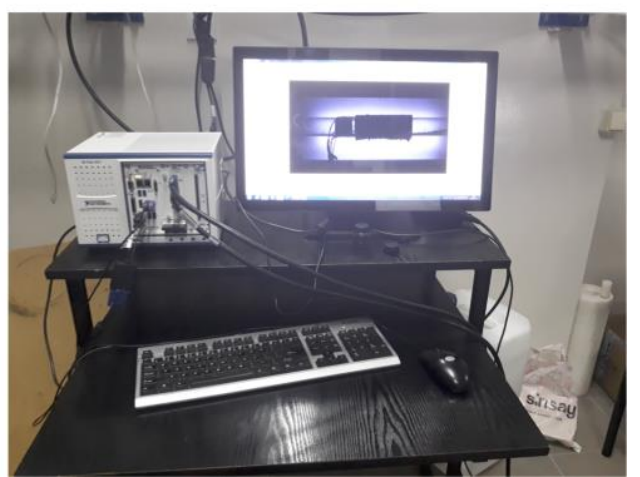

Fig. 1. Camera vision section: a) photography of measurement section,

b) photography of computer station dedicated to image processing and analysis

\section{Image processing algorithm}

The first important task of the designed image processing algorithm is the percentage estimate of the settled layer of granular material in the lower part of the horizontal transparent section of the pipeline. The area monitored by the camera, divided into two sections, allows to analysis the flow in separate two localizations. Using this fact, the algorithm responsible for image processing estimates flow state based on image area in the behind of sensor (area A) and in the front of sensor (area B).

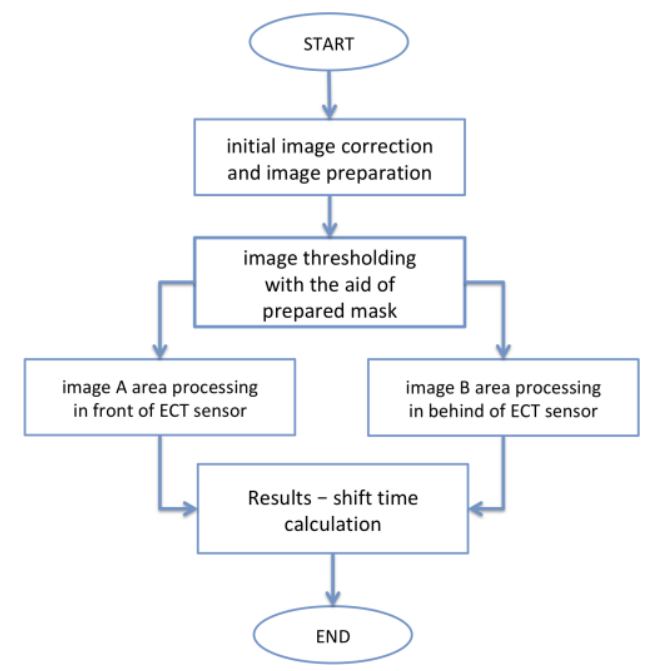

Fig. 2. Algorithm flowchart

Figure 2 shows the successive steps of the algorithm, which lead to the analysis of the flow inside the pipeline registered by the camera. The algorithm tries to detect and isolate transported material in both parts from recorded images. Then the average occupancy percentage is calculated in the section in front of the sensor and in the section after the sensor in real time. On the basis of these two information, the average percentage of material settled on the bottom of the pipeline is also calculated. In the first step of the presented algorithm, Fig. 2, the raw frame of the registered image is read in. It is shown in Fig. 4. The goal is to isolate and process only those parts of the image on which the transported material is located. Therefore, subsequent operations are aimed at achieving this result.

The next step in the process includes initial correction, image preparation and focuses on solving the previously described assumption. As part of this process, pre-processing operations are carried out to facilitate and speed up the further image processing. This process involves separating those parts of the image that bring unnecessary noise and increase the number of operations that need to be done in the next steps [17].

The video frame with an empty pipeline (Figure 3) is used to remove the background from images on which the material being transported is seen (Figure 4). The result of this operation is shown (Figure 5) where the areas in which the material is transported are shown, realizing the assumed goal. In the next step, the algorithm monitors and processes both pipeline sections - before and after the ECT sensor.

The next stage focuses on operations related to image thresholding and mask preparation. The result of this step is adequately depicted in the Fig 6. More details can be found in article [16]. This is an important element of the whole algorithm, because thanks to well-chosen filters and the thresholding method it helps to achieve the intended goal. The goal is to separate the image containing only material in the stream from the rest of the image. As a result of this stage of the algorithm, two areas have been designated which form the basis for further image processing.

The next stage of the algorithm involves processing the area in front of (area A) and behind the sensor (area B), the purpose of which is to determine the percentage occupancy level in both sections for each image frame being processed. Based on the level of material filling and determining the height of the pipeline, the algorithm is able to determine the percentage proportions of the material to the height of the pipeline. The result from this stage is shown in Fig. 7

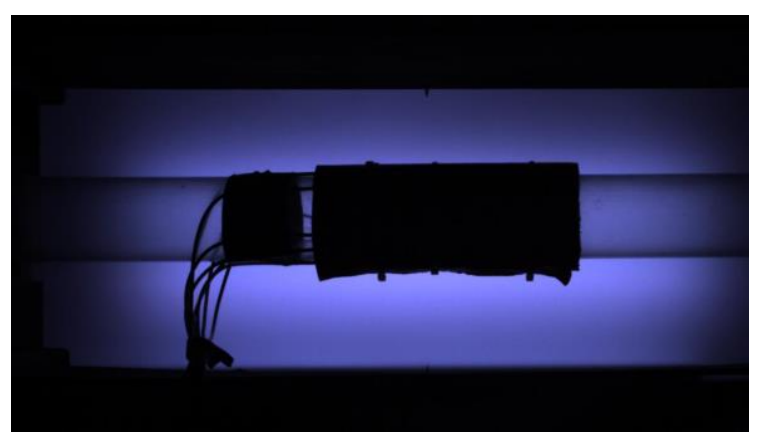

Fig. 3. Image of the empty pipeline (transparent measurement section) with the process tomography ECT sensor mounted

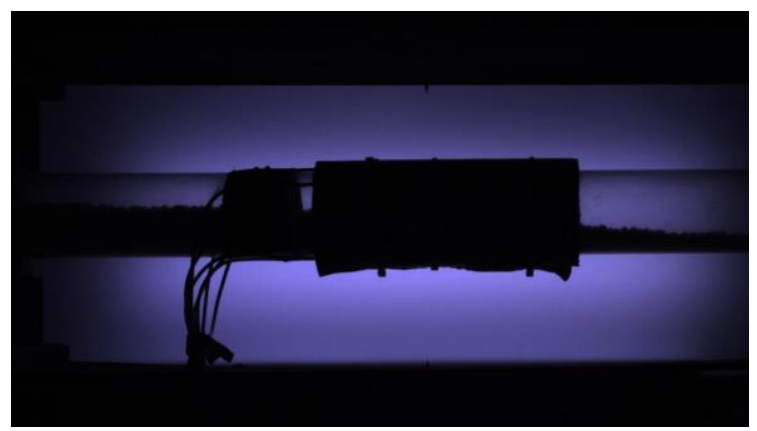

Fig. 4. Image frame for a normal operation records (white material flowing inside the pipeline)

Each section is additionally marked with a red contour in order to better visualize the achieved effect. Under each section there is a calculated percentage of filling in each of the monitored sections. The whole process is repeated for each new image frame 
loaded by the algorithm so that for each section, the average occupancy level of the pipeline is calculated in real time as shown in Figure 7. The algorithm calculates the percentage occupancy in the section in front of the sensor behind the sensor and outlines the areas that are processed At each moment, a processed image representing the level of fulfillment the pipeline is presented. The processed image is presented for each loaded raw frame, it facilitated verification of the extent to which the areas A and B were filled. Placing the obtained results on the graph showing changes in percentage fill in time where on the $\mathrm{x}$-axis the time from the moment of starting the installation to transfer bulk material is presented. On the other hand, the y axis will display the percentages of pipeline occupancy for each section.

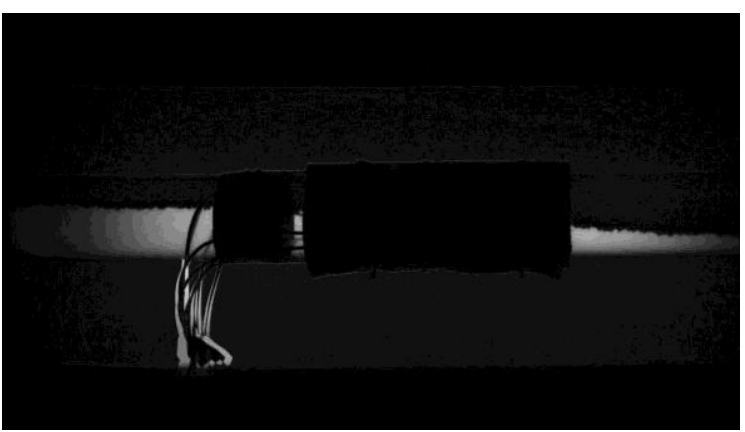

Fig. 5. The result of background removal based on comparison between the above images (Fig. 3 \& Fig. 4)

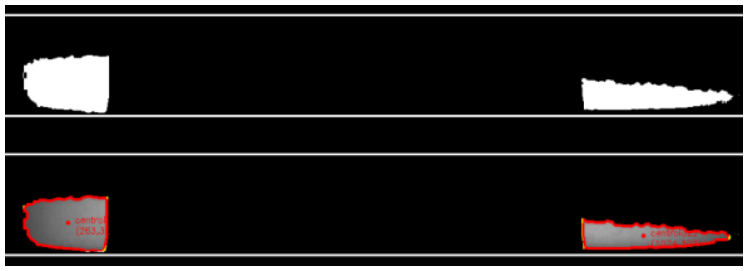

Fig. 6. Image thresholding with mask

The figure 8 shows the result of this operation. On the graph shows two waveforms, one section for the area in front of the sensor (area A), the other for the area behind the ECT sensor(area B). The figure shows a single frame with a fragment of the pipeline for a given moment in time.

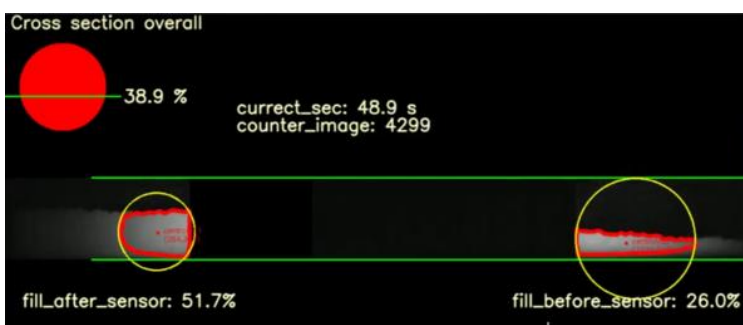

Fig. 7. Final result processing image
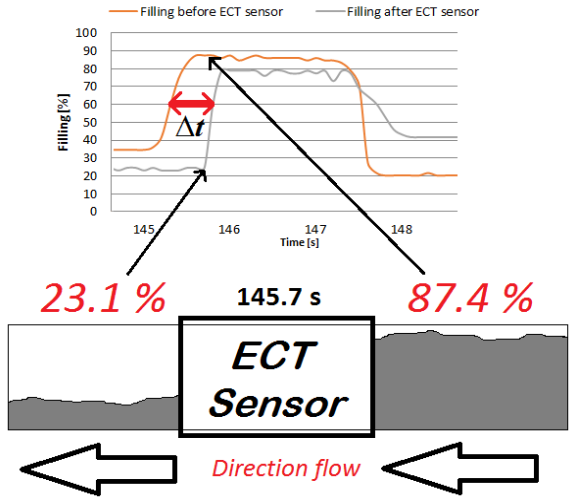

Fig. 8. Method of determining the transition time between the left and right part of the sensor

The material is transported in direction with the arrows in the drawing (from right to left). Both sections have a different occupancy level section on the right (before the sensor) $87.4 \%$ and the section on the left (behind the sensor) 23.1\%. Above the pipeline is a chart showing how the received data is placed on the graph.

The final step of the algorithm deals with placing the all processed data on the graph in order to present the entire process flow. The selected flow fragment is presented below to present the results achieved. The result is presented in Fig. 9.

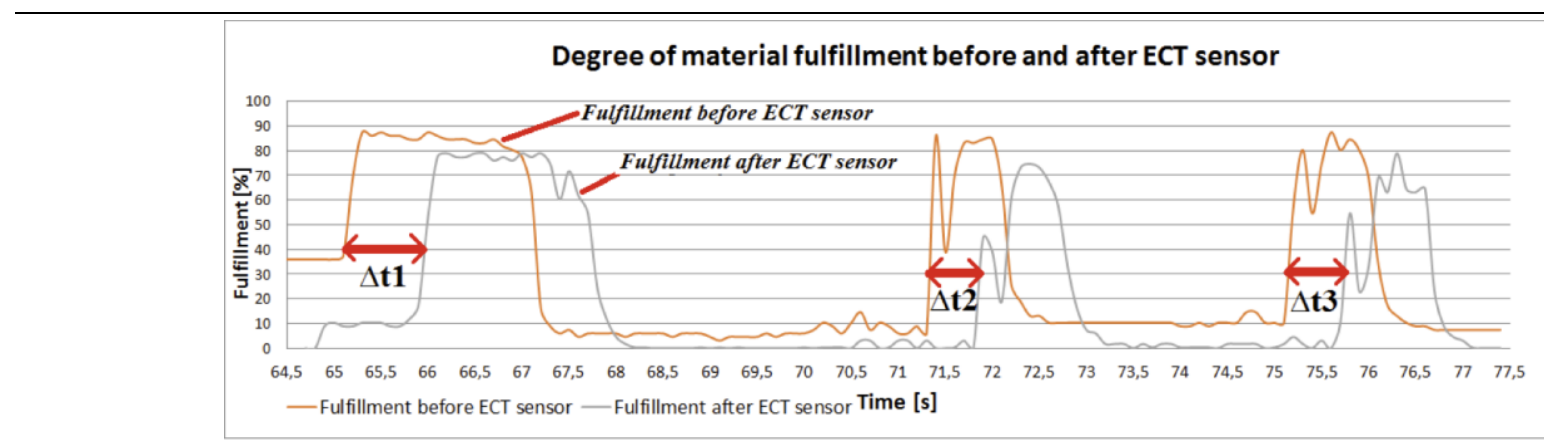

Fig. 9. Degree of material fulfillment before and after ECT sensor

\section{Result and discussion}

In figure 9 is shown the graph of the percentage occupancy in time for the area in front of the sensor and after the ECT sensor representing the final results. The figure shows a fragment of the processed bulk material transfer process. Three slugs of moving material are visible on it. The $\Delta \mathrm{t} 1, \Delta \mathrm{t} 2$ and $\Delta \mathrm{t} 3$ offsets have been marked on the graph. Analyzing the shift between the readings from both monitored sections $\Delta \mathrm{t} 1, \Delta \mathrm{t} 2$ and $\Delta \mathrm{t} 3$ based on the difference in the number of frames for each $\Delta t$, $\Delta \mathrm{t} 2$ and $\Delta \mathrm{t} 3$ offset, the approximate velocities of material movement were determined. Knowing the length of the ECT sensor, the sliding speed was calculated for each slug flow. The approximate speed was calculated for each displacement separately. They are within the range of $0.8-1.2 \mathrm{~m} / \mathrm{s}$.

\section{Conclusion}

The purpose of this article was to show how the speed of moving slug in bulk materials can be determined using a recorded image using fast cameras. A fast $100 \mathrm{kps}$ recording camera was used for the acquisition. The installed lighting in the tested part of the pipeline allows for a better image quality. Its contents present individual steps of the process that were carried out with the sample results obtained at each step of the process.

Also shown is the method in which the final result was obtained in the form of a graph presenting the percentage level of occupancy for each moment of the whole process, on which readings from both parts of the pipeline are presented. Based on the displacement between the readings from sections A and B which marked on the chart, the velocity of the slug flow was pre-calculated. 


\section{Acknowledgements}

This work was financed by the Lodz University of Technology, Faculty of Electrical, Electronic, Computer and Control Engineering and partially founded by Program Operacyjny Inteligentny Rozwój, NCBiR, Nowa generacja platformy tomografii przemystowej do diagnostyki i sterowania procesami technologicznymi, POIR.04.01.02-00-0089/17-00.

\section{Literature}

[1] Abdalellah O. Mohmmed, Mohammad S. Nasif, Hussain H. Al-Kayiem, Rune W. Time: Measurements of translational slug velocity and slug length using an image processing technique. Flow Measurement and Instrumentation 50/2016, 112-120

[2] Abdolahzare Z., Mehdizadeh S.A.: Nonlinear mathematical modeling of seed spacing uniformity of a pneumatic planter using genetic programming and image processing. Neural Computing and Applications 29/2018, 363-375, [DOI: 10.1007/s00521-016-2450-1].

[3] Chaniecki Z., Grudzień K., Jaworski T., Rybak G., Romanowski A., Sankowski D.: Diagnostic system of gravitational solid flow based on weight and accelerometer signal analysis using wireless data transmission technology. Diagnostic of gravitational solid 17(4)/2013, 319-326.

[4] Chaniecki Z., Sankowski D.: Monitorowanie i diagnozowanie stanów dynamicznych z użyciem tomografii procesowej. Diagnostyka procesów i systemów, Warszawa 2007, 388-394.

[5] Fiderek P., Wajman R., Kucharski J.: Fuzzy clustering based algorithm for determination for the two-phase gas-liquid flows similarity level. Przegląd Elektrotechniczny 90(2)/2014, 52-55.

[6] Gao L., Yan Y., Lu G.: Contour-based Image Segmentation for On-line Size distribution Measurement of Pneumatically Conveyed Particles. IEEE International Instrumentation and Measurement Technology Conference, Binjiang 2011, 1-5, [DOI: 10.1109/IMTC.2011.5944318].

[7] Grudzien K., Chaniecki Z., Romanowski A., Niedostatkiewicz M., Sankowski D.: ECT Image Analysis Methods for Shear Zone Measurements during Silo Discharging Process. Chinese Journal of Chemical Engineering 20(2)/2012, 337-345, [DOI:10.1016/S1004-9541(12)60396-6].

[8] Grudzień K., Chaniecki Z., Rybak G., Niedostatkiewicz M., Matusiak B., Romanowski A.: Multi-measurement system of gravitational flow process in slim large-scale silo. 7th World Congress on Industrial Process Tomography, WCIPT7, Kraków 2013.

[9] Grudzień K., Romanowski A., Chaniecki Z., Niedostatkiewicz M., Sankowski D.: Description of the silo flow and bulk solid pulsation detection using ECT. Flow Measurement and Instrumentation 21/2010, 198-206.

[10] Grudzien K., Romanowski A., Sankowski D. \& R. A. Williams (2007), Gravitational Granular Flow Dynamics Study Based on Tomographic Data Processing. Particulate, Science and Technology 26(1)/2008, 67-82, [DOI: $10.1080 / 02726350701759373$ ]

[11] Honkanen M., Eloranta H., Saarenrinne P.: Digital imaging measurement of dense multiphase flows in industrial processes. Flow Measurement and Instrumentation 21/2010, 25-32.

[12] Jaworski A.J., Dyakowski T.: Application of electrical capacitance tomography for measurement of gas-solids flow characteristics in a pneumatic conveying system. Meas. Sci. Technol. 12/2001, 1109-1119.

[13] Jaworski A.J., Dyakowski T.: Application of electrical capacitance tomography for measurement of gas-solids flow characteristics in a pneumatic conveying system. Meas. Sci. Technol. 12/2001, 1109-1119.

[14] Li J., Webb C., Pandiella S.S., Campbell G.M., Dyakowski T., Cowell A., McGlinchey D.: Solids deposition in low-velocity slug flow pneumatic conveying. Chemical Engineering and Processing 44/2005, 167-173.

[15] Mi Bo: Low-velocity pneumatic transportation of bulk solids. Ph.D. thesis, Department of Mechanical Engineering, University of Wollongong, 1994. http://ro.uow.edu.au/theses/83.

[16] Miłak M., Chaniecki Z., Sankowski D., Grudzień K., Romanowski A.: Image processing for evaluation of settled layer during pneumatic conveying of granular solids. IIPhDW 2018.

[17] Miłak M., Grudzień K., Romanowski A., Sankowski D.: Analysis of Slug Flows in Pneumatic Conveying of Solid based on CCD, IIPhDW 2017.

[18] Mosorov V.: Phase spectrum method for time delay estimation using twin-plane electrical capacitance tomography. Electronics letters 42(11)/2006, 0013-5194.

[19] Niederreiter G., Strauss M., Sommer K., Herrmann H.: Investigations on the formation and stability of plugs at dense-phase pneumatic conveying. International Congress for Particle Technology Nürnberg, PARTEC, 2004.

[20] Pan R., Wypych P.W.: Pressure drop and slug velocity in low-velocity pneumatic conveying of bulk solids. Powder Technology 94/1997, 123-132.

[21] Romanowski A., Grudzien K., Chaniecki Z., Wozniak P.: Contextual processing of ECT measurement information towards detection of process emergency states. 13th International Conference on Hybrid Intelligent Systems - HIS 2013, 291-297, [DOI: 10.1109/HIS.2013.6920448].

[22] Romanowski A., Grudzień K., Aykroyd R., Williams R.: Advanced Statistical Analysis as a Novel Tool to Pneumatic Conveying Monitoring and Control Strategy Development. Part. Part. Syst. Charact. 23(3-4)/2006, 289-296.

[23] Saoud A., Mosorov V., Grudzien K.: Measurement of velocity of gas/solid swirl flow using Electrical Capacitance Tomography and cross correlation technique. Flow Measurement and Instrumentation 53/2017, 133-140, [DOI: 10.1016/j.flowmeasinst.2016.08.003].

[24] Soleimani M., Mitchell CN., Banasiak R., Wajman R., Adler A.: Fourdimensional electrical capacitance tomography imaging using experimental data. Progress in Electromagnetics Research 90/2009, 171-180.

\section{M.Sc. Mateusz Milak}

e-mail:mmilak@iis.p.lodz.pl

Ph.D. student in the Institute of Applied Computer Science in Lodz University of Technology. $\mathrm{He}$ deal with processing image for two years. His field of interest concerns the electrical tomography, image processing and design algorithm to analyze industry methods to transport materials.

ORCID ID: 0000-0003-1887-2985

\section{M.Sc. Agnieszka Leszczyńska}

e-mail: a.leszczynska@iis.p.lodz.pl

Ph.D. student in the Institute of Applied Computer Science in Lodz University of Technology. In her work he deals with the issues in the field of electrical capacitance tomography, pneumatic transport, software engineering, image processing and recognition

ORCID ID: 0000-0002-2475-999X

\section{Ph.D. Eng. Krzysztof Grudzień}

e-mail: kgrudzi@iis.p.lodz.pl

Assistant Professor of Applied Computer Science at Lodz University of Technology. Member of Polish Information Processing Society and ACM Lodz Chapter. He obtained PhD in 2007 in the field of Computer Science, Process Tomography specialty. His research interests include applications of noninvasive imaging techniques and identification of dynamic industrial processes parameters, developmen of algorithms for image processing and analysis with particular reference to the analysis of sequences of 2D tomography images gathered from the ECT and $\mathrm{X}$-rays tomography systems.

ORCID ID: 0000-0003-4472-8100

\section{Ph.D. Eng. Andrzej Romanowski}

e-mail: androm@kis.p.lodz.pl

Doctor of Technical Sciences, Computer Science specialized in tomography measurement data processing and inverse problems, Lodz University of Technology 2008

Recent interests cover applications of tomography methods to industry as well as research on human factors in ubiquitous computing and human computer interaction. President of ACM and PIPS Łódź Chapters.

ORCID ID: 0000-0001-5241-0405

\section{Prof. Dominik Sankowsk}

e-mail: dsan@iis.p.lodz.pl

Professor of Applied Computer Science, at the Lodz University of Technology. He achieved a Ph.D. with distinction (1979), D.Sc. (habilitated doctor - 1989), and granted the title of professor (1998). Since 2001 he has held the position of full Professor. Member of: IEEE Computer Society, Group of Experts in the Computer Science specialization of National Accreditation Committee (PKA). Since many year Communication Director of International Society of Process Tomography (ISIPT). His research interests include Image Processing and Analysis, Pattern Recognition, Artificial Intelligence, Software Engineering, Data Processing, Real-Time Systems, IT Systems in Management, On-line Identification of Industrial Objects, Automation of the Thermal Processes.

ORCID ID: 0000-0003-2223-6690

otrzymano/received: 31.01 .2019 przyjęto do druku/accepted: 28.02 .2019
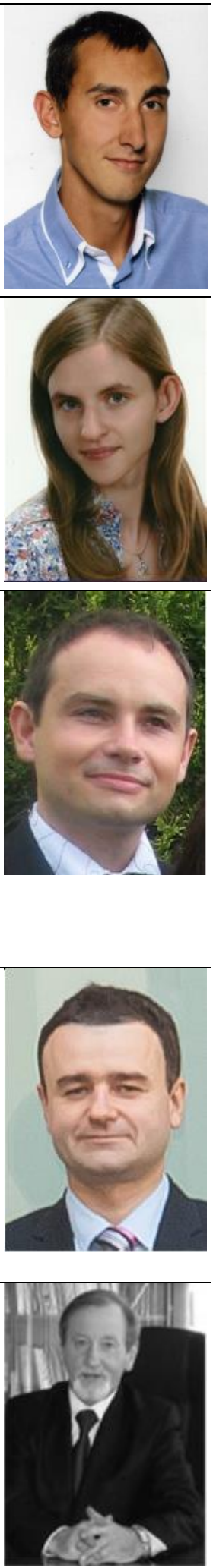